Arkadiusz Jełowicki

Muzeum Narodowe Rolnictwa i Przemysłu Rolno-Spożywczego w Szreniawie

Alicja Mironiuk Nikolska

Państwowe Muzeum Etnograficzne w Warszawie

Mariola Tymochowicz

Uniwersytet Marii Curie-Skłodowskiej w Lublinie, Muzeum Narodowe w Lublinie

\title{
II edycja Konkursu PTL - Nagroda im. Antoniego Kaliny w kategorii wystawa roku
}

\section{Posiedzenie jury}

W 2021 roku Zarząd Główny Polskiego Towarzystwa Ludoznawczego (PTL) ogłosił drugą edycję Konkursu PTL — Nagroda im. Antoniego Kaliny w „Kategorii II: najciekawsza wystawa o tematyce etnologicznej/antropologicznej”. Powołał przy tym komisję konkursową (jury) w składzie: dr Arkadiusz Jełowicki (PTL O/Poznań, Narodowe Muzeum Rolnictwa i Przemysłu Rolno-Spożywczego w Szreniawie), Alicja Mironiuk Nikolska (PTL O/Warszawa, Państwowe Muzeum Etnograficzne w Warszawie), dr hab. Mariola Tymochowicz (PTL O/Lublin, Uniwersytet im. M. Curie-Skłodowskiej), Zbigniew Wolanin PTL O/Kraków, Muzeum Okręgowe w Nowym Sączu) oraz Alicja Woźniak (PTL O/Łódź, Muzeum Archeologiczne i Etnograficzne w Łodzi). Ostatnia jurorka zgodziła się dołączyć do komisji konkursowej jako laureatka, autorka-kuratorka wystawy czasowej „Wzornik. Szycie opoczyńskie, łowickie, sieradzkie. Tradycja/trwanie/w 100 lecie województwa łódzkiego”, która w 2020 roku otrzymała Nagrodę im. A. Kaliny właśnie w tej kategorii. 
Na tegoroczny konkurs zgłoszono sześć wystaw, w tym cztery przygotowane przez muzea. Wszystkie zgłoszone ekspozycje zostały zakwalifikowane do dalszej procedury.

\section{Wstawy zgłoszone w 2021 roku:}

1. „Pomiędzy magią a religią”, organizator Muzeum Górnośląskie w Bytomiu; kuratorka: Anna Jurczyk, współpraca Anna GrabińskaSzczęśniak, Daria Misiak.

2. „Nad Wisłą, na Urzeczu”, organizator Państwowe Muzeum Etnograficzne w Warszawie, kurator: Mariusz Raniszewski, współpraca dr Justyna Laskowska-Otwinowska, Anita Broda.

3. „Ceramika Jana Limonta”, organizator Muzeum Etnograficzne im. prof. Marii Znamierowskiej Prüfferowej w Toruniu; kuratorzy: Grażyna Szelągowska, Jarosław Pawlikowski.

4. „Podlwowska wieś Sokolniki na dawnej fotografii”, organizator Muzeum Etnograficzne we Wrocławiu, kuratorki Hanna Golla, dr Małgorzata Michalska.

5. „Wystawa powarsztatowa koronki frywolitki. Mistrzyni frywolitki. Warsztaty koronki czółenkowej z Eugenią Wieczorek z Jarocina”, organizator Centrum Kultury i Sztuki w Kaliszu; kuratorka Anna Gałczyńska, współpraca Tomasz Sadło, Marta Pakulska.

6. „Podhalanie” organizator: Tatrzański Park Narodowy, inicjator wystawy: Szymon Ziobrowski, kuratorki Agnieszka Gąsienica-Giewont, dr hab. Stanisława Trebunia-Staszel, współpraca Jacek Poremba.

\section{Ocena wystaw}

19 sierpnia 2021 roku, w formie on-line, odbyło się posiedzenie jury. Po stwierdzeniu ważności zgłoszeń jury przystąpiło do prac. Ustalono wewnętrzną procedurę pomocniczą oceniania wystaw, w której zastosowano cztery kryteria opiniowania:

Pomysł/idea: Jaka była motywacja organizatorów do zrobienia wystawy, główny cel, główne założenia, pytania badawcze, które stawiali sobie autorzy scenariusza.

Kreacja/oprawa: Spójność z założeniami. Czy udało się zrealizować cele mery toryczne, społeczne i aranżacyjne. Czy widz (juror) odgaduje zamierzenia autorów. Ewentualne nowatorskie sposoby prezentacji. Równowaga 
pomiędzy dziełami i opisami. Czytelność etykiet muzealnych i ich sposób przekazu. Równowaga między obiektami, a opisami, multimediami etc.

Edukacja: Środki multimedialne. Gry (planszowe, inne). Działania interaktywne. Rozmaite i ciekawe pomysły na działania towarzyszące.

Promocja: Informacja o trwałych śladach wystawy - wydawnictwa, gadżety, sposoby dystrybuowania. Linki do mediów. Funkcjonowanie w mediach społecznościowych i innych. Informacja o frekwencji na wystawie.

Wyznaczono także punktację dla każdego kryterium — od 1 do 5 punktów. Każdy z członków/kiń jury samodzielnie punktował każdą z wystaw.

\section{Wynik Konkursu}

Jury wyraziło uznanie wszystkim organizatorom zgłoszonych do konkursu wystaw. Mimo trudności wynikających z ograniczeń związanych z pandemią COVID-19 włożyli oni olbrzymi trud w przygotowanie ekspozycji oraz ich udostępnienie, także on-line. Całe zespoły pracowników zrealizowały projekty, wykazując się mobilnością, elastycznością i kreatywnością w dostosowaniu do zmiennych warunków. Doceniając ten trud jury złożyło podziękowania i wyrazy szacunku dla znakomicie wykonanej pracy.

Nagrodę otrzymała wystawa wpisująca się w nurt klasycznych etnograficznych projektów muzealnych: „Ceramika Jana Limonta” z Muzeum Etnograficznego im. prof. M. Znamierowskiej-Prüfferowej w Toruniu. Celem ekspozycji jest przybliżenie życia i twórczości Jana Limonta od lat 30. do końca lat 70. XX w. Jego twórczość nawiązywała do garncarskich tradycji wileńskich, dlatego też na wystawie zaprezentowane zostały także przykładowe wyroby innych garncarzy wywodzących się z terenów Wileńszczyzny (głównie ceramika Aleksandra Azarewicza oraz anonimowa ceramika z Wilna datowana na okres międzywojenny). Zaprezentowano także prace wykonane przez Zbigniewa Limonta w latach 70. XX w. oraz narzędzia i przybory garncarskie pochodzące ze zbiorów Muzeum Etnograficznego w Toruniu. Na ekspozycji przedstawiono dokumenty i fotografie osobiste oraz rodzinne, a także szczególny film pt. Mój ojciec zrealizowany w latach 70. XX w. i dokumentujący pracę garncarza w warsztacie. Autorem filmu jest Zbigniew Limont, syn Jana, który przez pewien okres również zajmował się wyrobem ceramiki. To wzorcowo przygotowana wystawa monograficzna prezentująca biografię i dorobek znakomitego garncarza. Kryje się za tą realizacją żmudna praca badawcza dwojga dociekliwych kuratorów - Grażyny Szelągowskiej i Jarosława Pawlikowskiego, któ- 
rych rzetelność zawodowa zaowocowała zebraniem, a przede wszystkim uporządkowaniem ogromnej liczby artefaktów i źródeł. Dzięki ich pracy przywrócono pamięci kolejne niezwykle twórcze życie człowieka, którego życiowe losy przypominają historię wielu mieszkańców Torunia, ich powojenną tułaczkę, tworzenie nowej społeczności i najnowszej historii miasta. Przypomnienie Wilna, źródła wiedzy fachowej bohatera wystawy, ale także miejsca niezwykle ważnego dla wielu torunian kieruje uwagę w stronę własnych rodzin. Realizacja świadczy także o wysokiej pozycji muzeum, jako instytucji zaufania publicznego, bo to właśnie do muzeum rodzina garncarza przekazała ponad pięć tysięcy obiektów, ufając, że zostaną właściwie chronione i spopularyzowane. Godna podkreślenia jest spójna wizualnie, starannie zaprojektowana aranżacja wystawy, oddająca klimat poszczególnych jej części: miejsc życia i pracy Limonta i niezwykłą galerię jego wyrobów ceramicznych. Na podkreślenie zasługują przemyślane działania promocyjne i program edukacyjny skupiony wokół szeroko rozumianego garncarstwa: warsztaty ceramiczne, wykłady spotkania z garncarzami. Zajęcia prowadzone w przestrzeni wystawy z pewnością wpłyną na jej odbiór przez dzieci i młodzież. Towarzyszący wystawie katalog zawierający oprócz tekstów kuratorów znakomite fotografie wyrobów. J. Limonta. Novum wymuszonym przez pandemię jest udostępnianie treści w Internecie. Muzeum Etnograficzne w Toruniu zaprezentowało filmy przybliżające pracę wszystkich osób tworzących wystawę, dając przykład znakomitej współpracy pracowników instytucji.

\section{Nagrody}

Jury zaproponowało także by we wrześniu 2021 na Walnym Zgromadzeniu Delegatów PTL w Przysusze wręczyć w sposób uroczysty nagrody-dyplomy. 